\title{
The Emergence of Profit and Interest in the Monetary Circuit
}

\author{
Egmont Kakarot-Handtke ${ }^{1}$ \\ University of Stuttgart, Institute of Economics and Law, Germany
}

\begin{abstract}
Efficient progress of the monetary theory of production (MTP) is hampered by an unsatisfactory account of how profit and interest emerge in the monetary circuit. As matter of fact, this question puzzled already the classics. It seems evident that it cannot be answered by applying the usual tools. The present paper's purpose is to overcome the deadlock. This is done by setting the circulation approach on general structural axiomatic foundations.
\end{abstract}

JEL B41, B59, E19, E40

Key words: new framework of concepts, structure-centric, axiom set, monetary circuit, quantity of money, transaction money, profit, distributed profit, rate of interest, profit ratio equalization

"The existence of monetary profits at the macroeconomic (aggregate) level has always been a conundrum for theoreticians of the monetary circuit. If money is created from bank credit, how can we explain profits if firms borrow just enough to cover wages that are simply spent on consumption goods an returned to firms to extinguish their initial debt? Indeed, not only are firms unable to create profits, they also cannot raise sufficient funds to cover the payment of interest." (Rochon, 2005, p. 125), see also (Godley \& Lavoie, 2007, p. 3), (Messori \& Zazzaro, 2005, pp. 111-112), (Paraguez \& Seccareccia, 2000, pp. 109-110), (Smithin, 1994, p. 176)

It is the purpose of the present paper to solve these conundrums. This is done by setting the circulation approach on a comprehensive axiomatic foundation. The general thesis says that human behavior does not yield to the axiomatic method (this rules out the standard approach), yet the axiomatization of the money economy's fundamental structure is feasible. The general case for structural axiomatization has been made elsewhere (2011a), (2011b), thus we can immediately take up circuit theory as specific application.

The formal ground is prepared in Section 1. The analytical point of departure, Schumpeter's 'reasonably small number of equations connecting a reasonably small number of variables', is given with the structural axiom set which represents the pure consumption economy. In Sections 0 and 0 the relations between the household and the business sector's respective stock of money, the quantity of money, and the average stock of transaction money are defined. In Sections 0 and 0 the connection between profit, distributed profit, retained profit and saving is established. This yields the general complementary relation between retained profit and saving-dissaving. In Section 0 the self-reproducing process of profit origination and distribution is constituted. In the final part, Sections 0 to 0 the transaction and banking unit of the central bank are introduced. This enables the determination of all prices and the loan interest rate under the conditions of, at first, zero profit, and then under positive overall profits. Section 0 concludes.

\footnotetext{
${ }^{1}$ Affiliation: University of Stuttgart, Institute of Economics and Law, Keplerstrasse 17, D-70174 Stuttgart. Correspondence address: AXEC-Project, Egmont Kakarot-Handtke, Hohenzollernstraße 11, D- 80801 München, Germany, e-mail: handtke@axec.de
} 


\section{World Economic Review}

\section{Axioms and definitions}

The first three structural axioms relate to income, production, and expenditures in a period of arbitrary length. For the remainder of this inquiry the period length is conveniently assumed to be the calendar year. Simplicity demands that we have at first one world economy, one firm, and one product.

Total income of the household sector $Y$ in period $t$ is the sum of wage income, i.e. the product of wage rate $W$ and working hours $L$, and distributed profit, i.e. the product of dividend $D$ and the number of share $N$.

$$
Y=W L+D N \quad \mid t
$$

Output of the business sector $O$ is the product of productivity $R$ and working hours.

$$
O=R L \quad \mid t
$$

Consumption expenditures $C$ of the household sector is the product of price $P$ and quantity bought $X$.

$$
C=P X \quad \mid t
$$

The axioms represent the pure consumption economy, that is, no investment expenditures, no foreign trade, and no taxes or any other state activity.

Definitions are supplemented by connecting variables on the right-hand side of the identity sign that have already been introduced by the axioms (Boylan \& O'Gorman, 2007, p. 431). With (4) wage income $Y_{W}$ and distributed profit income $Y_{D}$ is defined:

$$
Y_{W} \equiv W L \quad Y_{D} \equiv D N \quad \mid t
$$

Definitions add no new content to the set of axioms but determine the logical context of concepts. New variables are introduced with new axioms.

The economic meaning is rather obvious for the set of structural axioms. What deserves mention is that total income in (1) is the sum of wage income and distributed profit and not of wage income and profit. Profit and distributed profit are quite different things that have to be thoroughly kept apart.

"A theory consists of a number of assumptions which logically function as axioms. Through specification and by introducing initial conditions, we may deduce predictions from them. If the predictions prove to be valid we may also say that the assumptions are realistic." (Klant, 1994, p. 75)

\section{Money and credit}

The dichotomization of the real and the monetary sphere was a central point of Keynes's methodological critique of conventional economics:

"The division of economics between the theory of value and distribution on the one hand and the theory of money on the other hand is, I think, a false division." (Keynes, 1973, p. 293)

The first task, then, is to demonstrate how money follows consistently from the axiom set. If income is higher than consumption expenditures the household sector's stock of money increases. The change in period $t$ is defined as: 


\section{World Economic Review}

$$
\Delta \overline{\mathrm{M}}_{\mathbf{H}} \equiv^{m} Y-C \quad \mid t
$$

The identity sign's superscript $m$ indicates that the definition refers to the monetary sphere.

The stock of money $\overline{\mathrm{M}}_{\mathbf{H}}$ at the end $\bar{t}$ of an arbitrary number of periods is defined as the numerical integral of the previous changes of the stock plus the initial endowment:

$$
\overline{\mathrm{M}}_{\mathbf{H}} \equiv \sum_{t=1}^{t} \Delta \overline{\mathrm{M}}_{\mathbf{H} t}+\overline{\mathrm{M}}_{\mathbf{H} 0} \mid \bar{t}
$$

The changes in the stock of money as seen from the business sector are symmetrical to those of the household sector:

$$
\Delta \overline{\mathrm{M}}_{\mathbf{B}} \equiv^{m} C-Y \quad \mid t
$$

The business sector's stock of money at the end of an arbitrary number of periods is accordingly given by:

$$
\overline{\mathrm{M}}_{\mathbf{B}} \equiv \sum_{t=1}^{t} \Delta \overline{\mathrm{M}}_{\mathbf{B} t}+\overline{\mathrm{M}}_{\mathbf{B} 0} \mid \bar{t}
$$

In order to reduce the monetary phenomena to the essentials it is supposed that all financial transactions are carried out by the central bank. The stock of money then takes the form of current deposits or current overdrafts (cf. (Wicksell, 1936, p. 70), (Renversez, 1996), (Lavoie, 2003, pp. 506-509)). Initial endowments can be set to zero. Then, if the household sector owns current deposits according to (6) the current overdrafts of the business sector are of equal amount according to (8), and vice versa. Each sector's stock of money is either positive or negative. Money and credit are at first symmetrical. From the central bank's perspective the quantity of money at the end of an arbitrary number of periods is then given by the absolute value either from (6) or (8):

$$
\overline{\mathrm{M}} \equiv\left|\sum_{t=1}^{t} \Delta \overline{\mathrm{M}}_{\mathbf{H} t ; \mathbf{B} t}\right| \quad \text { with } \quad \overline{\mathrm{M}}_{\mathbf{H} 0 ; \mathbf{B} 0}=0 \quad \mid \bar{t}
$$

The quantity of money is always $\geq 0$ and follows directly from the axioms. It is assumed at first that the central bank plays an accommodative role and simply supports the autonomous market transactions between the household and the business sector. For the time being, money is the dependent variable.

\section{Transaction money}

"In different ways, advocates of MTP [monetary theory of production] reject the simultaneous logic of general equilibrium analysis. They consider ... the need for analyzing the successive phases of the economic process." (Fontana \& Realfonzo, 2005, p. 9)

By sequencing the initially given period length of one year into months the idealized transaction pattern that is displayed in Figure 1 results (cf. (Newlyn, 1971), (Schmitt, 1996, p. 134)). It is assumed that the monthly income $\frac{Y}{12}$ is paid out at mid-month. In the first half of the month the daily spending of $\frac{Y}{360}$ increases the current overdrafts of the households. At mid-month the households change to the positive side and have current deposits of $\frac{Y}{24}$ at their disposal. This amount reduces continuously towards the end of the month. This pattern is exactly repeated over the rest of the year. At the end of each subperiod, and therefore also at the end of the year, both the stock of money and the quantity of money is zero. Money is present and absent depending on the time frame of observation. 


\section{World Economic Review}

Figure 1: Household sector's transaction pattern for different nominal incomes in two periods

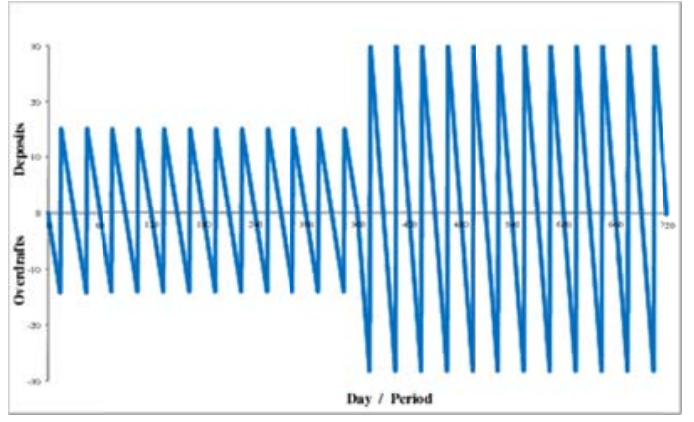

(a) Transaction pattern over two periods

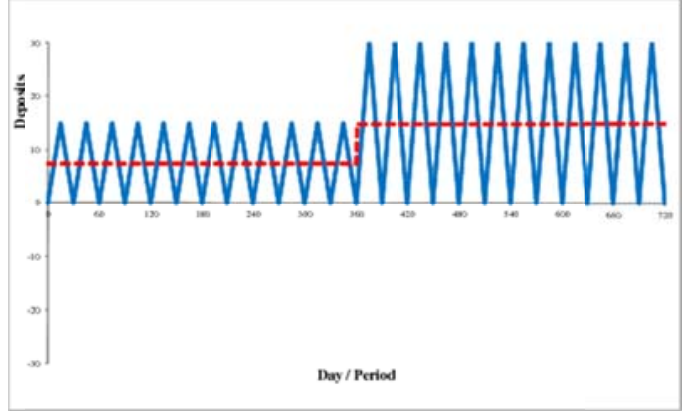

(b) Average stock of transaction money $\hat{\mathrm{M}}_{T}$

In period $_{2}$ the wage rate, the dividend and the price is doubled. Since no cash balances are carried forward from one period to the next, there results no real balance effect provided the doubling takes place exactly at the beginning of period 2 .

From the perspective of the central bank it is a matter of indifference whether the household or the business sector owns current deposits. Therefore, the pattern of Figure 1a translates into the average amount of current deposits in Figure $1 \mathrm{~b}$. This average stock of transaction money depends on income according to the transaction equation

$$
\hat{\mathrm{M}}_{T} \equiv \kappa Y \quad \mid t
$$

which resembles Pigou's Cambridge equation; the underlying theory, though, is thereby not adopted. For the regular transaction pattern that is here assumed as a idealization the index is $\frac{1}{48}$. Different transaction patterns are characterized by different numerical values of the transaction pattern index.

For formal convenience the expenditure ratio $\rho_{E}$ and the sales ratio $\rho_{X}$ is defined as:

$$
\rho_{E} \equiv \frac{C}{Y} \quad \rho_{X} \equiv \frac{X}{O} \quad \mid t
$$

An expenditure ratio $\rho_{E}=1$ indicates that consumption expenditures are equal to income, or, in other words, that the household sector's budget is balanced. A value of $\rho_{X}=1$ of the sales ratio means that the quantities produced and sold are equal in period $t$ or, in other words, that the product market is cleared. Taking (10) and (11) together one gets the explicit transaction equation for the limiting case of market clearing and budget balancing:

$$
\text { (i) } \hat{\mathrm{M}}_{T} \equiv \kappa \frac{\rho_{X}}{\rho_{E}} R L P \quad \text { (ii) } \frac{\hat{\mathrm{M}}_{T}}{P}=\kappa O \quad \text { if } \quad \rho_{X}=1, \rho_{E}=1 \quad \mid t \text {. }
$$

We are now in the position to substantiate the notion of accommodation as a money-growth formula. According to (i) the central bank enables the average stock of transaction money to expand or contract with the development of productivity, employment, and price. In other words, the real average stock of transaction money, which is a statistical artifact and no physical stock, is proportional to output (ii) if the transaction index is given and if the ratios $\rho_{E}$ and $\rho_{X}$ are unity. Under these initial conditions money is endogenous (Desai, 1989, p. 150) and neutral (Patinkin, 1989) in the structural axiomatic context. Money emerges from 


\section{World Economic Review}

autonomous market transactions and has three aspects: stock of money $\left(\overline{\mathrm{M}}_{\mathbf{H}}, \overline{\mathrm{M}}_{\mathbf{B}}\right)$, quantity of money (here $\bar{M}=0$ at period start and end because of $\rho_{E}=1$, cf. (Graziani, 1996, p. 143)) and average stock of transaction money (here $\hat{\mathbf{M}}_{T}>0$ ).

\section{Profit}

The business sector's financial profit in period $t$ is defined with (13) as the difference between the sales revenues - for the economy as a whole identical with consumption expenditures $C$ - and costs - here identical with wage income $Y_{W}:^{2}$

$$
\Delta \bar{Q}_{f i} \equiv C-Y_{W} \quad \mid t
$$

In explicit form, after the substitution of (3) and (4), this definition is identical with that of the theory of the firm:

$$
\Delta \bar{Q}_{f i} \equiv P X-W L \quad \mid t .
$$

Using the first axiom (1) and the definitions (4) one gets:

$$
\Delta \bar{Q}_{f i} \equiv C-Y+Y_{D} \quad \mid t
$$

The three definitions are formally equivalent. If distributed profit $Y_{D}$ in (15) is set to zero, then profit or loss of the business sector is determined solely by expenditures and income. For the business sector as a whole to make a profit consumption expenditures $C$ have in the simplest case to be greater than wage income $Y_{W}$. So that profit comes into existence in the pure consumption economy the household sector must run a deficit at least in one period. This in turn makes the inclusion of the financial sector mandatory. A theory that does not include at least one bank that supports the concomitant credit expansion (6) cannot capture the essential features of the market economy (Keynes, 1973, p. 85). Mention should be made that, for quite different reasons, neither neoclassicals nor Keynesians ever came to grips with profit (Desai, 2008, p. 10), (Tómasson \& Bezemer, 2010, pp. 1-4). There is no difference on this point with circuitists, or, for that matter, with heterodox attempts (e.g. (Correa, 2012), (Keen, 2010), (Bruun \& Heyn-Johnsen, 2009), (Binswanger, 1996)).

\section{Retained profit and saving}

Profits can either be distributed or retained. If nothing is distributed, then profit adds entirely to the financial wealth of the firm. Retained profit $\Delta \bar{Q}_{r e}$ is defined for the business sector as a whole as the difference between profit and distributed profit in period $t$ :

$$
\Delta \bar{Q}_{r e} \equiv \Delta \bar{Q}_{f i}-Y_{D} \mid t
$$

\footnotetext{
${ }^{2}$ Profits from changes in the value of nonfinancial assets are neglected here, i.e. the condition of market clearing $O=X$ holds throughout. For details about changes of inventory see (2011c, p. 5). Changes in the value of other nonfinancial assets are treated at length in (2012b).
} 
Using (15) and (7) it follows:

$$
\Delta \bar{Q}_{r e} \equiv C-Y \equiv^{m} \Delta \overline{\mathbf{M}}_{\mathbf{B}} \mid t .
$$

Retained profit $\Delta \bar{Q}_{r e}$ is the residual $C-Y$ as it appears at the firm that represents the business sector. The same residual appears at the central bank as a change of the business sector's stock of money $\Delta \overline{\mathrm{M}}_{\mathbf{B}}$. The two aspects are kept apart by the notation. It follows immediately that the development of the business sector's stock of money, which may carry a positive or negative sign, is given by (8).

Financial saving is given by (18) as the difference of income and consumption expenditures. This definition is identical with Keynes's (1973, p. 63), only the notation is different.

$$
\Delta \bar{S}_{f i} \equiv Y-C \quad \mid t
$$

In combination with (5) this yields the straightforward relation:

$$
\Delta \bar{S}_{f i} \equiv Y-C \equiv^{m} \Delta \bar{M}_{\mathbf{H}} \mid t .
$$

Financial saving $\Delta \bar{S}_{f i}$ is the residual $Y-C$ as it appears at the household sector; the same residual appears at the central bank as a change of the household sector's stock of money $\Delta \overline{\mathrm{M}}_{\mathbf{H}}$.

The two aspects are kept apart by the notation. It follows immediately that the development of the household sector's stock of money, which may carry a positive or negative sign, is given by (6). Equations (19) respectively (17) determine the changes of the quantity of money as given by (9).

Financial saving (19) and retained profit (17) always move in opposite directions, i.e. $\Delta \bar{Q}_{r e} \equiv-\Delta \bar{S}_{f i}$.

Let us call this the complementarity corollary because it follows directly from the definitions themselves. The corollary asserts that the complementary notion to saving is not investment but negative retained profit. Positive retained profit is the complementary of dissaving. This entails that the plans of households and firms are only mutually compatible if both retained profit and financial saving are zero. This rarely happens in the real world. Therefore, a behavioral equilibrium in the sense of Arrow and Hahn (1991, p. 16), although formally possible, plays no role in the structural axiomatic context.

In the general case, profit or loss depends on consumer spending and profit distribution. If distributed profit is set to zero, then we face, according to (15), three logical alternatives: $C<Y_{W}, C=Y_{W}$ or $C>Y_{W}$.

The first alternative entails a loss for the business sector as a whole, the second entails zero profit, and only the third leads to profit which in turn is the indispensable condition for a reproducible economy. Hence the real question is not about the existence of a zero-profit equilibrium, but how the market economy can, and in fact does, avoid this predicament over a longer time span. What is needed for a start is the deficit spending of the household sector at least in one period. When the purchase of long lived consumption goods, e.g. houses, is correctly subsumed under consumption expenditures there arises no problem with regard to collateral for the banking industry and a sound credit expansion may - in principle - proceed for an indefinite time in the pure consumption economy. It needs hardly emphasis that the process of profit origination looks different in the investment economy (for details see (2011d)). The underlying mechanism, though, is essentially the same.

In the pure consumption economy one has labor input as the sole factor of production and wage income as the corresponding factor remuneration. Since the factor capital is nonexistent, profit cannot be assigned to it in functional terms. From this follows as far-reaching methodological consequence: to treat profit as factor income is a category mistake (for a proof see (2012a)). 


\section{World Economic Review}

\section{Profit and profit distribution}

If, with distributed profit at first set to zero, consumption expenditures get ahead of wage income, i.e. $\rho_{E}>1$, the household and business sector's transaction patterns diverge in period 2 as shown in Figure 2. The household sector's current overdrafts increase until period end and, as a perfect mirror image, the business sector's current deposits increase, too.

Figure 2: Dissaving leads in period $_{2}$ to an increase of the household sector's current overdrafts and the business sector's current deposits; at the beginning of period $_{3}$ the household sector takes up a loan and profits are fully distributed

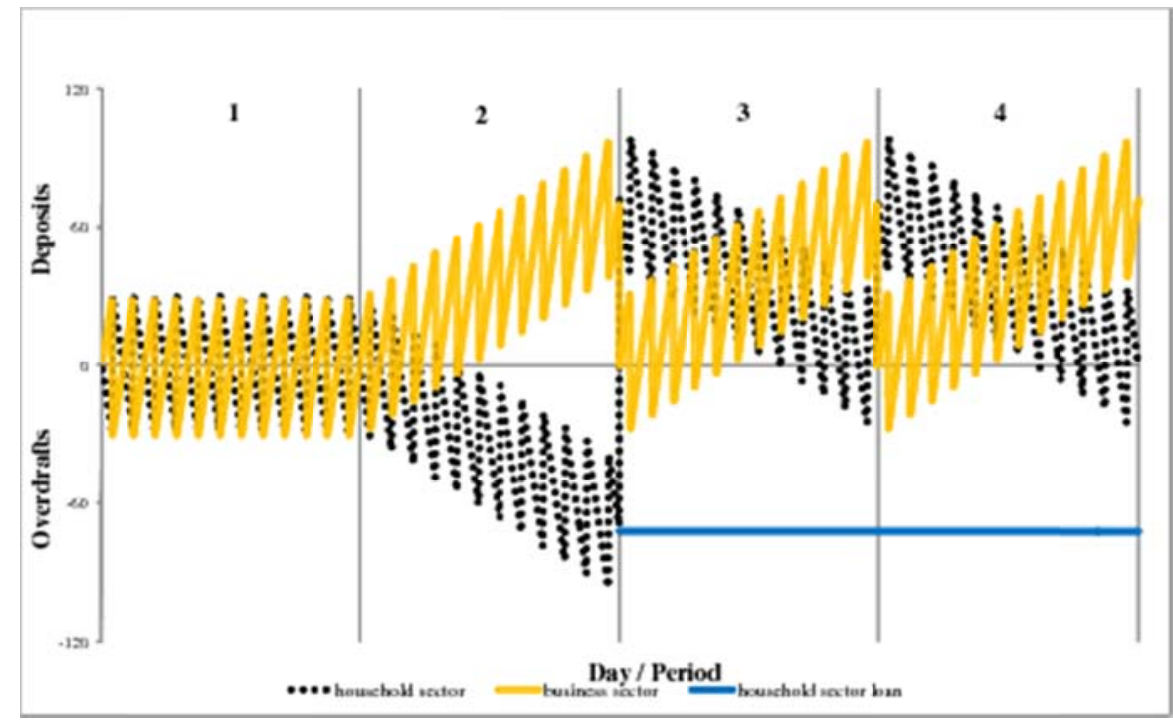

It is assumed that the household sector consolidates the overdrafts and takes up a one-period loan at the banking unit of the central bank exactly at the beginning of period ${ }_{3}$. This reduces overdrafts to zero. The household sector switches from short term liabilities, in fact the shortest possible term, to longer term liabilities.

The business sector posts a profit at the end of period 2 according to (15). It is assumed that this profit is fully distributed at the beginning of period ${ }_{3}$. This reduces the business sector's current deposits to zero and at the same time increases the household sector's deposits by the same amount. It therefore holds that distributed profit in period $_{3}$ is exactly equal to profit in period $_{2}$ :

$$
Y_{D 3}=\Delta \bar{Q}_{f i 2} \text {. }
$$

In period $_{3}$ the households no longer dissave but spend their distributed profits. Total consumption expenditures are equal to total income, i.e. $\rho_{E}=1$, as they were in $\operatorname{period}_{1}$. From this follows the profit in $\operatorname{period}_{3}$ as:

$$
\Delta \bar{Q}_{f i 3} \equiv \underbrace{C_{3}-Y_{3}}_{0}+Y_{D 3} \Rightarrow \Delta \bar{Q}_{f i 3}=\Delta \bar{Q}_{f i 2} .
$$

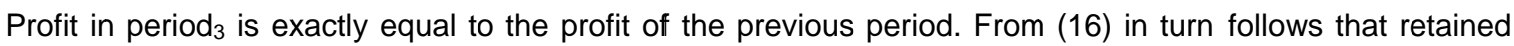
profit is zero. This pattern is repeated in period $_{4}$ and it is evident that this configuration is reproducible for an indefinite time span provided that profits are fully distributed and fully spent and the one-period loans are 


\section{World Economic Review}

prolonged in each successive period. The transaction pattern index $\kappa$ in (12), assumes different numerical values in period $_{2}$ and period $_{3}$. Subsequently it remains constant. This entails an increase of the average stock of transaction money beginning with period $_{2}$. The quantity of money (9) is, after profit distribution, zero at the beginning of period $_{3}$ and then at the beginning of the following periods.

\section{The transaction unit}

The business sector consists of a consumption goods producing firm $A$ and the central bank as the second firm $B$. To begin with, the central bank handles only the money transactions. Total employment is given by:

$$
L \equiv L_{A}+L_{B} \quad \mid t
$$

To focus exclusively on the monetary phenomena variations of total employment are excluded.

Total income consists according to (1) of wage income and distributed profit. To simplify the analysis the wage rates for all firms are set equal. Distributed profits are at first zero:

$$
Y=\underbrace{W_{A}}_{W} L_{A}+\underbrace{W_{B}}_{W} L_{B}+\underbrace{\left(D_{A} N_{A}+D_{B} N_{B}\right)}_{Y_{D}=0} \mid t .
$$

The household sector apportions its consumption expenditures between the purchase of consumption goods and the purchase of transaction services. With $X_{B}$ the number of transactions per period that are carried out by the central bank on behalf of the households is denoted:

$$
C=P_{A} X_{A}+P_{B} X_{B} \mid t
$$

Consumption expenditures are equal to income, i.e. $\rho_{E}=1$. The households neither save nor dissave. Overall financial profit (14) is differentiated for the two firms:

$$
\begin{aligned}
\Delta \bar{Q}_{f i A} & \equiv P_{A} X_{A}-W L_{A} \\
\Delta \bar{Q}_{f i B} & \equiv P_{B} X_{B}-W L_{B}
\end{aligned}
$$

Under the condition of market clearing, i.e. $\rho_{X}=1$, this can be rewritten as:

$$
\begin{aligned}
& \Delta \bar{Q}_{f i A}=P_{A} R_{A} L_{A}\left(1-\frac{W}{P_{A} R_{A}}\right) \text { if } \rho_{X A}=1 \\
& \Delta \bar{Q}_{f i B}=P_{B} R_{B} L_{B}\left(1-\frac{W}{P_{B} R_{B}}\right) \text { if } \rho_{X B}=1
\end{aligned}
$$

Overall profits are zero because of $C=Y$ and $Y_{D}=0$. The zero profit condition for a single firm reads $\frac{W}{P R}=1$. Under this conditions follows from (26) that absolute prices are equal to unit wage costs, i.e. $P_{A}=\frac{W}{R_{A}}$ respectively $P_{B}=\frac{W}{R_{B}}$. In sum: both markets are cleared, the household sector's budget is balanced and profits are zero for both the consumption goods producing firm and the transaction unit of the central bank. Money transactions consume resources, the less so the higher the productivity of the transaction unit is. Alone for this reason money cannot be neutral. The price the households pay for each transaction $P_{B}$ follows from (26) and the zero profit condition. 


\section{World Economic Review}

\section{The banking unit}

The inclusion of the banking unit entails that the given resources of the business sector $L$ have first to be reallocated:

$$
L \equiv L_{A}+L_{B}+L_{C} \mid t
$$

As a consequence total income is then given by:

$$
Y=\underbrace{W_{A}}_{W} L_{A}+\underbrace{W_{B}}_{W} L_{B}+\underbrace{W_{C}}_{W} L_{C}+\underbrace{\left(D_{A} N_{A}+D_{B} N_{B}+D_{C} N_{C}\right)}_{Y_{D}=0} \mid t .
$$

The interest payments of the household sector to the banking unit have to be subsumed under consumption expenditures:

$$
\begin{gathered}
C=P_{A} X_{A}+P_{B} X_{B}+\mathrm{I}_{C} \overline{\mathrm{A}}_{C} \mid t . \\
C=C_{A}+C_{B}+C_{C}
\end{gathered}
$$

The quantity bought from the banking unit $X_{C}$ can here be replaced by the amount of the loan $\overline{\mathrm{A}}_{C}$ (for the consistent derivation of the rate of interest from the differentiated axiom set see (2011b, pp. 12-14)).

The reallocation of labor input is neutral with regard to the price of the consumption good. When labor input $L_{C}$ is taken away from firm $A$ output falls. At the same time consumption expenditures are redirected away from purchases of consumption goods to purchases of the services of the banking unit, i.e. $C_{A}$ goes down and $C_{C}$ goes up. This leaves the price of the consumption good unaffected under the given conditions. The household sector buys less consumption goods and more banking services. According to this demand shift the unaltered total labor input is reallocated.

Profit for each firm is zero, i.e. $\frac{W}{P R}=1$ :

$$
\begin{aligned}
& \Delta \bar{Q}_{f i A}=P_{A} R_{A} L_{A}\left(1-\frac{W}{P_{A} R_{A}}\right) \text { if } \rho_{X A}=1 \\
& \Delta \bar{Q}_{f i B}=P_{B} R_{B} L_{B}\left(1-\frac{W}{P_{B} R_{B}}\right) \text { if } \rho_{X B}=1 \\
& \Delta \bar{Q}_{f i C}=I_{C} \bar{A}_{C}\left(1-\frac{W}{I_{C} \frac{\bar{A}_{C}}{L_{C}}}\right) \text { if } \rho_{X C}=1
\end{aligned}
$$

The zero profit conditions and the market clearing condition define the commodity price, the transaction price and the rate of interest. All are equal to the respective unit wage costs. The inclusion of the banking unit and the appearance of interest on the one-period loan results in a reallocation of demand and resources. The loan interest rate is, at first, alone determined by the production conditions of the banking unit. The same holds for the price of the consumption good $P_{A}$ and the price of a monetary transaction $P_{B}$. All firms recoup their costs. Interest payments of the households on the one-period-loan are equal to wage income in the banking unit. All relative prices are objectively determined by the respective productivities. The case for business loans is analogous (for details see (2011c, pp. 2-7)). 


\section{World Economic Review}

\section{Equal profit ratios}

In order to eliminate all subjective elements and to determine all prices analytically for the general case of positive overall profit an additional assumption is required. The most suitable condition is profit ratio equalization. The overall profit ratio $\rho_{Q}$ follows from (15) as:

$$
\rho_{Q} \equiv \frac{\Delta \bar{Q}_{f i}}{W L} \Rightarrow \rho_{Q} \equiv \rho_{E}\left(1+\rho_{D}\right)-1 \quad \mid t
$$

The profit ratio $\rho_{Q}$ for the business sector as a whole is positive if the expenditure ratio $\rho_{E}$ is $>1$ or the distributed profit ratio $\rho_{D}$ is $>0$, or both. The distributed profit ratio is defined as:

$$
\rho_{D} \equiv \frac{Y_{D}}{Y_{W}} \mid t
$$

The profit ratio for each firm is then given by:

$$
\rho_{Q A} \equiv \frac{P_{A} X_{A}}{W_{A} L_{A}}-1 \quad \rho_{Q B} \equiv \frac{P_{B} X_{B}}{W_{B} L_{B}}-1 \quad \rho_{Q C} \equiv \frac{\mathrm{I}_{C} \overline{\mathrm{A}}_{C}}{W_{C} L_{C}}-1 \quad \mid t .
$$

Under the condition of equal profit ratios $\rho_{Q A}=\rho_{Q B}=\rho_{Q C}=\rho_{Q}$ follows for the market clearing prices and the rate of interest:

$$
\begin{aligned}
& P_{A}=\frac{W}{R_{A}} \rho_{E}\left(1+\rho_{D}\right) \text { if } \rho_{X A}=1 \\
& P_{B}=\frac{W}{R_{B}} \rho_{E}\left(1+\rho_{D}\right) \text { if } \rho_{X B}=1 \quad \mid t . \\
& \mathrm{I}_{C}=\frac{W}{\frac{\bar{A}_{C}}{L_{C}}} \rho_{E}\left(1+\rho_{D}\right) \text { if } \rho_{X C}=1
\end{aligned}
$$

If the overall expenditure ratio $\rho_{E}$ is unity and the distributed profit ratio $\rho_{D}$ is zero then prices and the interest rate are equal to unit wage cost in each firm as in (30). In the general case, prices and the interest rate depend also on the expenditure ratio and the distributed profit ratio. An expenditure ratio $\rho_{E}$ of unity and a distributed profit ratio $\rho_{D}>0$ yields the reproducible configuration of Figure 2 which entails both interest and profit. Relative prices are the same as in the zero profit case.

Equations (34) looks like markup pricing formulas. They are nothing of the sort. The prices are determined by the conditions of market-clearing and equal profit ratios. The introduction if the markup assumption would over-determinate the system. Yet the equations go some way in explaining why most economic models of pricing 'derive a reasonably stable markup of price over cost' (Hall, 2011, p. 446).

It is evident that profit ratio equalization is a formal benchmark. Whether profit ratios in fact equalize in the real world is a quite different matter. This, though, is of secondary importance. The indispensable 


\section{World Economic Review}

condition for a viable money economy is that overall profits are greater than zero. In the pure consumption economy this means that the household sector must produce an initial deficit. In a more complex economy the investing business sector (2011d), the foreign trade sector (2011e) or the government sector (2012c) may spark off and maintain an expansionary trend. The basic principle is the same. What the monetary economy needs least is an equilibrium with balanced budgets.

\section{Conclusions}

Behavioral assumptions, rational or otherwise, are not solid enough to be eligible as first principles of theoretical economics. Hence all endeavors to lay the formal foundation on a new site and at a deeper level actually need no further vindication. The present paper suggests three non-behavioral axioms as groundwork for the circuitist approach. The main results of this paradigmatic application are:

- The quantity of money follows directly from the set of structural axioms.

- Under the initial conditions of market clearing and budget balancing money is endogenous and neutral.

- A positive expenditure-income asymmetry is the ultimate structural originator of profit and therefore the indispensable prerequisite for favorable business conditions. This holds for the elementary consumption economy and the complex investment economy in equal measure.

- In the pure consumption economy total profit of the business sector is greater than zero if the expenditure ratio is $>1$ or the distributed profit ratio is $>0$, or both.

- In the pure consumption economy one has labor input as the sole factor of production and wage income as the corresponding factor remuneration. Since the factor capital is nonexistent, profit cannot be assigned to it in functional terms. From this follows as far-reaching methodological consequence: to treat profit as factor income is a category mistake.

- Under the condition of full profit distribution profit remains constant and retained profit is zero. This configuration is reproducible for an indefinite time span.

- Loans are produced like any other commodity. The rate of interest inherits the role of the price.

- Under the condition of profit ratio equalization all prices and the rate of interest on one-period loans to the household sector are objectively determined. Relative prices depend solely on the productivities in the different lines of production.

\section{References}

Arrow, K. J., \& Hahn, F. H. (1991). General Competive Analysis. Amsterdam, New York: North-Holland.

Binswanger, M. (1996). Money Creation, Profits, and Growth: Monetary Aspects of Economic Evolution. In E. Helmstädter, \& M. Perlman (Eds.), Behavioral Norms, Technological Progress, and Economic Dynamics (pp. 413-437). Ann Arbour: University of Michigan Press.

Boylan, T. A., \& O'Gorman, P. F. (2007). Axiomatization and Formalism in Economics. Journal of Economic Surveys, 21(2), pp. 426-446.

Bruun, C., \& Heyn-Johnsen, C. (2009). The Paradox of Monetary Profits: An Obstacle to Understanding Financial and Economic Crisis? Economics E-Journal, Discussion Papers, 2009-52.

Correa, R. (2012). The Determination of Profits. World Economic Journal, Article Review Online, Accessed February 6th 2012.

Desai, M. (1989). Endogenous and Exogenous Money. In J. Eatwell, M. Milgate, \& P. Newman (Eds.), Money (pp. 146-150). London, Basingstoke: Macmillan.

Desai, M. (2008). Profit and Profit Theory. In S. N. Durlauf, \& L. E. Blume (Eds.), The New Palgrave Dictionary of Economics Online (2nd ed., pp. 1-11). Basingstoke: Palgrave Macmillan. 


\section{World Economic Review}

Fontana, G., \& Realfonzo, R. (2005). Introduction: The Monetary Theory of Production. Tradition and Perspectives. In G. Fontana, \& R. Realfonzo (Eds.), The Monetary Theory of Production (pp. 1-19). Houndmills, Basingstoke, New York: Palgrave Macmillan.

Godley, W., \& Lavoie, M. (2007). Monetary Economics. An Integrated Approach to Credit, Money, Income and Wealth. Houndmills, Basingstoke, New York: Palgrave Macmillan.

Graziani, A. (1996). Money as Purchasing Power and Money as a Stock of Wealth in Keynesian Economic Thought. In G. Deleplace, \& E. J. Nell (Eds.), Money in Motion (pp. 139-154). Houndmills, Basingstoke, New York: Macmillan.

Hall, R. E. (2011). The Long Slump. American Economic Review, 101(2), 431-469.

Kakarot-Handtke, E. (2011a). Keynes's Missing Axioms. SSRN Working Paper Series, 1841408, 1-32.

Kakarot-Handtke, E. (2011b). The Pure Logic of Value, Profit, Interest. SSRN Working Paper Series, 1838203, pp. 1-25.

Kakarot-Handtke, E. (2011c). Reconstructing the Quantity Theory (II). SSRN Working Paper Series, 1903663, pp. 1-19.

Kakarot-Handtke, E. (2011d). Squaring the Investment Cycle. SSRN Working Paper Series, 1911796, pp. 125.

Kakarot-Handtke, E. (2011e). Trade, Productivity, Income, and Profit: The Comparative Advantage of Structural Axiomatic Analysis. SSRN Working Paper Series, 1970895, pp. 1-23.

Kakarot-Handtke, E. (2012a). The Common Error of Common Sense: An Essential Rectification of the Accounting Approach. Levy Economics Institute Working Papers, 731, pp. 1-28.

Kakarot-Handtke, E. (2012b). Primary and Secondary Markets. Levy Economics Institute Working Papers, 741, pp. 1-27.

Kakarot-Handtke, E. (2012c). Taxes, Profits, and Employment: A Structural Axiomatic Analysis. SSRN Working Paper Series, 1995025, pp. 1-23.

Keen, S. (2010). Solving the Paradox of Monetary Profits. Economics E-Journal, 4(2010-31).

Keynes, J. M. (1973). The General Theory of Employment Interest and Money. London, Basingstoke: Macmillan.

Klant, J. J. (1994). The Nature of Economic Thought. Aldershot, Brookfield: Edward Elgar.

Lavoie, M. (2003). A Primer on Endogenous Credit-Money. In L.-P. Rochon, \& S. Rossi (Eds.), Modern Theories of Money (pp. 506-543). Cheltenham, Northampton: Edward Elgar.

Messori, M., \& Zazzaro, A. (2005). Single-Period Analysis: Financial Markets, Firms' Failures and Closure of the Monetary Circuit. In G. Fontana, \& R. Realfonzo (Eds.), The Monetary Theory of Production. Tradition and Perspectives. (pp. 111-123). Houndmills, Basingstoke, New York: Palgrave Macmillan.

Newlyn, W. T. (1971). Theory of Money (2nd ed.). Oxford: Clarendon Press.

Paraguez, A., \& Seccareccia, M. (2000). The Credit Theory of Money: The Monetary Circuit Approach. In J. Smithin (Ed.), What is Money? (pp. 101-123). London, New York: Routledge.

Patinkin, D. (1989). Neutrality of Money. In J. Eatwell, M. Milgate, \& P. Newman (Eds.), Money (pp. 273287). London, Basingstoke: Macmillan.

Renversez, F. (1996). Monetary Circulation and Overdraft Economy. In G. Deleplace, \& E. J. Nell (Eds.), Money in Motion (pp. 465-488). Houndmills, Basingstoke, London: Macmillan. 


\section{World Economic Review}

Rochon, L.-P. (2005). The Existence of Monetary Profits within the Monetary Circuit. In G. Fontana, \& R. Realfonzo (Eds.), The Monetary Theory of Production. Tradition and Perspectives. (pp. 125-138). Houdmills, Basingstoke, New York: Palgrave Macmillan.

Schmitt, B. (1996). A New Paradigm for the Determination of Money Prices. In G. Deleplace, \& E. J. Nell (Eds.), Money in Motion (pp. 104-138). Houndmills, Basingstoke, London: Macmillan.

Smithin, J. (1994). Controversies in Monetary Economics. Aldershot, Brookfield: Edward Elgar.

Tómasson, G., \& Bezemer, D. J. (2010). What is the Source of Profit and Interest? A Classical Conundrum Reconsidered. MPRA Paper, 20557, pp. 1-34.

Wicksell, K. (1936). Interest and Prices. London: Macmillan. 